\title{
Beliefs, Values and Morals: The Philosophical Underpinnings of Dysthanasia
}

\author{
Filipe Monteiro \\ Consultant Pneumologist (Retired), CHLN Pneumologia 1, Santa Maria University Hospital, Lisbon, Portugal \\ Email: jfpmonteiro@yahoo.com
}

How to cite this paper: Monteiro, F. (2016). Beliefs, Values and Morals: The Philosophical Underpinnings of Dysthanasia. Open Journal of Philosophy, 6, 406-411.

http://dx.doi.org/10.4236/ojpp.2016.64037

Received: September 26, 2016

Accepted: October 30, 2016

Published: November 2, 2016

Copyright (@) 2016 by author and Scientific Research Publishing Inc.

This work is licensed under the Creative

Commons Attribution International

License (CC BY 4.0).

http://creativecommons.org/licenses/by/4.0/

(c) (i) Open Access

\begin{abstract}
In medical practice, the treatment and prognosis in the end of life has associated to ethical dilemmas, which are established in conformity with individual or collective beliefs and values. Dysthanasia from Greek, means to make death difficult, and it is currently an ethical problem with significant consequences. Considering that death itself has two moments, the process of death and the moment of death, dysthanasia is the undue prolongation of the process of death with the help of technological devices that allows the life sustaining procedures. Although it is through the technological advances that the moment of death can be delayed, it is the beliefs and values that are deep rooted in the sub conscience of the physicians that are responsible for the demeanor of end of life ethical dilemmas. Beliefs and values when encompassed in areas like phenomenology of knowledge, dialectic of technology, conflict of values and existentialism and metaphysics, can somehow explain this issue that is current, emerging and compelling.
\end{abstract}

\section{Keywords}

Dysthanasia, End of Life, Ethical Dilemmas, Death

\section{Introduction}

Beliefs, values and morals, although abstract concepts are deep rooted in the sub conscience of every adult individual and constitute a moral system whose application oversees every action in our daily life.

In medical practice, the end of life is associated with a number of ethical dilemmas. This is particularly with regard to treatment and prognosis, which are established in conformity with individual or collective beliefs and values.

While euthanasia is a much discussed end of life ethical problem which commonly find its way onto the media headlines, dysthanasia-the medical futility-draws much 
less attention, and yet it has remained the main reason for the movement of legalization of the former (euthanasia).

\section{Beliefs and Values: Terminology}

Beliefs, values and morals are founding structures of the conscience of an individual and collectively, of every society.

Using a plain definition, beliefs are abstract principles regarding judgments about ourselves and the world around. Beliefs include an action or thing and if that action or thing is good or bad. Beliefs can influence our behaviors, even our thoughts.

On the other hand, values are the rules by which we make decisions about good and bad, right and wrong and should or shouldn't.

They are also abstract, hierarchical and dynamic concepts that are a ground for our behavior and motivation.

In a scale of values, morals have a greater social element and tend to have a very broad recognition.

Ultimately the behavior set on beliefs and values are judged morally by the society as good or bad.

\section{Concept of Dysthanasia}

The timeline of humanity shows us evolution in almost every field of arts and science. In science, the advances have come through the knowledge and technology, which is itself the result of applied knowledge.

In medicine, the aftermath of this evolution has contributed, together with social improvement of many societies, to a progressive and sustained increase in life expectancy.

The increase in life expectancy owes much of its accomplishments, so far as Medicine is concerned, to the technological achievements which can directly influence the natural history of end of life.

In terms of concept, the end of life or death has two moments: The process of death and the moments of death. While the latter is the moment of irreversibility, the former-the process of death-can be swayed in either way; in fastening-euthanasia or in retarding-dysthanasia.

Dysthanasia from Greek, dysthanatos, turning death difficult. In a broad sense it can be understood as medical stubbornness or a futile treatment. In good medical practice the treatment should be proportional to the expected prognosis. If the treatment provided clearly overcomes the expected prognosis retarding the process of dying and prolonging the agony and suffering of the patient, than it seems clear that it is a case of dysthanasia.

The answerability to this dubious medical practice falls on doctors that treat patients in their end of life, mostly those working in the intensive care units.

It is surprising to verify that in a study conducted by the European Society of Intensive Care Medicine a significant percentage of intensivists (73\%) admit patients with 
no hope of survival to an intensive care unit and still more surprising that around 40\% will deliberately administer large doses of drugs until death ensues (Vincent, 1999).

What could explain this demeanor in doctors whose daily assignment is to deal with patients in their end of life battle?

"I am I and my circumstance, and, if I do not save it, I do not save myself." A quote from Ortega y Gasset, the famous philosopher, can somehow explain this, otherwise, incongruous behavior.

The individual and the circumstances are closely interrelated. That is, they cannot be separated and they settle on beliefs and values, which are also interconnected.

In this context, I believe, a set of behaviors, beliefs and values can explain the underlying rationale that can unravel this unethical posture that is dysthanasia (Monteiro, 2006).

\section{Dysthanasia: The Underlying Rationale}

\subsection{Defensive Medicine}

The reason for being of dysthanasia has been bestowed on defensive medicine, a physician response, fully or partly prompted, to protect him from an incrimination of bad medical practice.

The defensive medicine can be positive or negative. In the first case the physician carries out unnecessary procedures to guard against that accusation, while in the second situation he avoids the procedures to safeguard from the same accusation.

So far as dysthanasia is concerned, it is the positive defensive medicine that is at stake.

In short, we can say that in defensive medicine, the physician procedures result not from his deep rooted values and beliefs but from the self-protection against charges of malpractice, in the event of an unfavorable outcome of treatment, by the society.

\subsection{Phenomenology of Knowledge}

The prevailing leitmotiv in the inspiration of dysthanasia is centered in the eventuality of a diagnostic inaccuracy, which is inherent to the medical practice that can be explained at the light of analysis of phenomenology of knowledge, or to be more precise in the field of epistemology.

Contextualizing the medical procedure at the light of this philosophical method, the doctor is the "subject" (master of knowledge), the patient as the "object" (one who is to be known) and the disease as the representation through which the physician knows the patient.

For knowledge to exist it is necessary that the "subject" (physician) masters the "object" (patient). Is that possible?

The statement by the positive-to believe that through senses and reasoning, the subject can fully understand the object-constitutes the dogmatism.

In a medical procedure, a dogmatic attitude would imply that a physician can through his senses and human reasoning, have absolute trust regarding the patient and 
his disease. It is to believe that through scientific knowledge, the diagnosis, the treatment and the prognosis are infallible.

In practice the medical procedures are subject to statistical laws with all the variables that settle the result. That is the reason why the uncertainty, although minimum, can always exist.

The difficulty in meeting the absolute truth does not apply, in its essence, to the medical procedures since the uncertainty of absolute knowledge does not mean a total unawareness in relation to knowledge. Thus the radical skepticism, a doctrine that rejects one or more items of putative knowledge should be rejected.

On the alternative is the moderate skepticism which can be considered as a relieved pattern of dogmatism, since it admits that the subject is capable to master the object and the representation, although in a circumscribed form.

Analyzing the two slopes of moderate skepticism-the probabilism and the relativism-it appears that the probabilism applies in a more balanced manner to the medical practice since its thesis claims that a precise knowledge is not possible-there are no certainties between the setting up of a judgment and the reality. Thus there is no strict assurance but only a probability. This uncertainty, can itself explain the dysthanasia.

So far as relativism-relative truth-is concerned, it can take two forms: the subjectivism - that limits the validity of truth to the subject who knows and judges-and the relativism itself-according to which all the truth is relative.

In the first situation the knowledge is dependent on the on variables of knower; the relativism accentuates the dependency on external factors.

Thus the dysthanasia or medical futility can be explained either by the subjectivismthe individual uncertainty of the concerned physician-or by the relativism-while making the knowledge dependent on external factors (which in a medical procedure can be related to the available diagnostic tools).

The great twentieth century heritage of knowledge is in the words of Edgar Morin "The knowledge of the limits of the knowledge; the certainty of elimination of uncertainties." (Morin, 1999).

\subsection{Dialectic of Technology}

It is well known that the dialectic is inherent to the technology. A justification for the therapeutic obstinacy could find a support in the overspecialization, characteristic to the high technology, which leads to the fractioning of the knowledge; this entails to the splitting of skills that ends up in the unaccountability in the decision making process.

In the advanced stages of some diseases when the multi organ failure foresees an unfavorable prognosis, the unaccountability of the various experts in regarding the inevitable outcome can explain the maintenance of the treatments.

\subsection{Conflict of Values}

The collision of values can also explain the therapeutic obstinacy. This can be found out in the universal Declaration of Human Rights, signed on $10^{\text {th }}$ December of 1948 by the United Nations General Assembly. 
In Article 3, it states that "Everyone has the right to life, liberty and security of person", while in Article 5 it says that "No one shall be subjected to torture or to cruel, inhuman or degrading treatment or punishment” (Universal Declaration Human Rights, 1948).

These two articles are facing each other especially when apparently it is a situation of therapeutic obstinacy. It is a situation of conflict of values and rights and thus, an ethical conflict since what is at stake is opposing imperatives.

\subsection{Existentialism and Metaphysics}

The impact of technology in the conceit of death, changed thoroughly, in the developed countries, the way of staring the end of life.

Through the intervention of technology, the moment of death has been heralded by the process of death. These two moments-the moment of death and the process of death-beget different feelings.

As for the moment of death, according to Ernest Becker "The fall into self-consciousness, the emergence from comfortable ignorance in nature, had one great penalty for man: it gave him dread, or anxiety." (Becker, 1973).

However, Ernst Bloch denies this anguish of death and refuses the failure, having in mind that there is always an exit-the hope (Block, 1982). This escape from anguish conceived by the moment of death and hope bring in transcendence in the process of death can explain the use of technology in dystanasia.

\section{Concluding Remarks}

The dignity and the protection of human life is the supreme value in the civilized world. Even before the dawn of modern civilization, the eagerness for perennial life or the quest for eternity was searched through the exercise of medicine.

The science of medicine evolved gradually throughout the centuries, from an empiric to an evidence based science.

One of the most outstanding conquests of medical science is its contribution to the life expectancy-from barely 36 years in the middle of nineteenth century to almost 79 years in 2011.

Much of this progress owes its reality to the tremendous evolution of technology. However, we should bear in mind that medicine is a science of probabilities and not an exact science, and, as such, its practice has inherent to it the uncertainty.

How to deal with the uncertainty of medical prognostication in the end of life? Acting according to one's own beliefs and values? Or in consonance, with the beliefs and values regulated by a set of norms and behaviors — code of ethics—of a society?

Beliefs and values are abstract concepts of an individual. When they overcome the boundaries of the self and are enfolded by the society due to its broad acceptance, beliefs and values become the cornerstone of any field that frames the societies.

However, it is worth to bear in mind that beliefs and values, contain the seeds of dualism and, here and then, some uncertainties. 
In dysthanasia, these less assertive expressions of beliefs and values can unfold the reason for being of dysthanasia.

\section{References}

Becker, E. (1973). The Denial of Death. New York: The Free Press.

Block, E. (1982). Le Principe Esperance (pp. 52-55). Paris: Gallimard Editions.

Monteiro, F. (2006). Ventilação mecânica e obstinação terapêutica ou distanásia, a dialéctica da alta tecnologia em medicina intensiva. Revista Portuguesa de Pneumologia, XII, 281-291. http://dx.doi.org/10.1016/S0873-2159(15)30431-1

Morin, E. (1999). La tête bien faite. Portuguese Edition. Lisboa: Instituto Piaget.

Universal Declaration Human Rights (1948). www.un.org/en/

Vincent, J.-L. (1999). Forgoing Life Support in Western European Intensive Care Units: The Results of an Ethical Questionnaire. Critical Care Medicine, 27, 1626-1633.

http://dx.doi.org/10.1097/00003246-199908000-00042

Submit or recommend next manuscript to SCIRP and we will provide best service for you:

Accepting pre-submission inquiries through Email, Facebook, LinkedIn, Twitter, etc. A wide selection of journals (inclusive of 9 subjects, more than 200 journals)

Providing 24-hour high-quality service

User-friendly online submission system

Fair and swift peer-review system

Efficient typesetting and proofreading procedure

Display of the result of downloads and visits, as well as the number of cited articles Maximum dissemination of your research work

Submit your manuscript at: http://papersubmission.scirp.org/

Or contact ojpp@scirp.org 